\title{
PERSPEKTYWY BADAŃ HISTORYCZNO-WOJSKOWYCH CZASÓW JANA III SOBIESKIEGO
}

\author{
Marek Wagner \\ Uniwersytet Przyrodniczo-Humanistyczny w Siedlcach
}

\section{ABSTRACT \\ PROSPECTS OF MILITARY HISTORY RESEARCH OF THE TIMES OF JOHN III SOBIESKI}

The article reviews the current status and prospects of the research in the field of the Polish military affairs and warfare in the times of John III. An analysis of the present literature leads to a conclusion that the most important needs in the field include the development of a synthesis of the Polish-Turkish war of 1684-1699, a history of the Polish cavalry and artillery corps in the second half of the $17^{\text {th }}$ century and, above all, a full scholarly account of the generalship of John III Sobieski.

Keywords: John Sobieski, Polish army, historiography.

Słowa kluczowe: Jan Sobieski, wojsko polskie, historiografia.

W 1958 roku znakomity znawca czasów Jana Sobieskiego Janusz Woliński zasygnalizował potrzebę podjęcia nowych badań historycznych nad wojskowością koronną i litewską za panowania Jana III. Postulował wówczas pilne zajęcie się wybranymi zagadnieniami badawczymi, a więc takimi jak analiza niektórych kampanii wojennych czy sprawy organizacyjno-wojskowe, ocena sztuki wojennej Sobieskiego oraz jego pracy dowódczej, biografistyka wojskowa, a nawet zbadanie ówczesnej strategii, sztuki operacyjnej i taktyki wojska polskiego w drugiej połowie XVII wieku' ${ }^{1}$.

1 J. Wolińs ki, Wojskowość polska w dobie Jana III Sobieskiego (stan i problemy badań) [w:] idem, $Z$ dziejów wojny i polityki $w$ dobie Jana Sobieskiego, red. M. Anusiewicz, Warszawa 1960, s. 186192 - jest to tekst referatu wygłoszonego 14 IX 1958 r. na posiedzeniu Sekcji Historii Wojskowości VIII Powszechnego Zjazdu Historyków Polskich w Krakowie. 
Od 1960 roku polska historiografia wojskowa systematycznie już realizowała wytyczone przez Profesora Janusza Wolińskiego cele naukowe, trzeba tu wskazać zwłaszcza dorobek Jana Wimmera, wybitnego badacza wojskowości nowożytnej oraz autora wielu klasycznych monografii naukowych ${ }^{2}$. Mieli oni, i nadal mają, niezaprzeczalny wpływ na wybór zainteresowań naukowych kolejnych pokoleń historyków i podejmowane zadania badawcze czy wreszcie tworzenie w kręgach akademickich środowisk zajmujących się problematyką historyczno-wojskową doby Jana III Sobieskiego.

Z konieczności w tym krótkim przeglądzie muszę pominąć cenne prace poświęcone bardzo istotnym problemom związanym z szeroko rozumianym życiem rodzinnym Jana Sobieskiego, działalnością jego latyfundium magnackiego, mecenatem naukowym i artystycznym, także propagandą polityczną dworu królewskiego Sobieskich. Wymieniam także jedynie najważniejsze studia i najlepsze pod względem naukowym rozprawy, bo nie sposób w tym miejscu przypomnieć bardzo bogatego dorobku polskiej historiografii, odnoszącego się do czasów hetmaństwa czy panowania Jana Sobieskiego, na przykład w badaniach nad dziejami parlamentaryzmu i nowożytną biografistyką, przypominam jedynie cenną i klasyczną już biografię hetmana i monarchy autorstwa Zbigniewa Wójcika³ .

W aspekcie badań nad historią sztuki wojennej i dziejami wojen Jana III Sobieskiego dotychczasowy dorobek polskich badaczy jest zróżnicowany - wojna polsko-turecka w latach 1672-1676 ma wprawdzie naukową monografię mego autorstwa opublikowaną w 2009 roku$^{4}$, jednak nadal pewne fragmenty zmagań zbrojnych, zwłaszcza z perspektywy Imperium Osmańskiego, można poddać pogłębionej analizie historyczno-wojskowej. Nie miałem dostępu do archiwaliów niemieckich, moskiewskich i białoruskich, stąd konieczność ich wykorzystania i nowego spojrzenia na wspomniany konflikt zbrojny pomiędzy Rzecząpospolitą a Portą.

Kampania wiedeńska 1683 roku ma już rzetelną naukową monografię z roku 1983, autorstwa znakomitego historyka wojskowości Jana Wimmera ${ }^{5}$, zatem opis i analiza odsieczy wiedeńskiej oraz jej generalne oceny nadal pozostają aktualne w dorobku polskiej historiografii wojskowej. Mimo to pojawiło się kilka cennych przyczynków historycznych dotyczących kampanii i bitwy wiedeńskiej, na przykład na temat relacji między Janem III a księciem Karolem Lotaryńskim ${ }^{6}$, organizacji chorągwi husarskich, a także ówczesnych formacji kozackich ${ }^{7}$. Nie spełniła jednak

2 J. Wimmer, Wojsko polskie w drugiej polowie XVII wieku, Warszawa 1965 (wyd. 2 poszerz.: Oświẹcim 2013); idem, Wiedeń 1683. Dzieje kampanii i bitwy, Warszawa 1983.

Z. Wójcik, Jan Sobieski 1629-1696, Warszawa 1983.

4 M. Wagner, Wojna polsko-turecka w latach 1672-1676, t. I-II, Zabrze 2009.

5 J. Wimmer, Wiedeń $1683 \ldots$

6 M. Nagielski, K. Bobiatyński, Jan III Sobieski i Karol Lotaryński w kampanii wiedeńskiej 1683 roku, „De Re Militari” 2015, t. I, s. 76-87.

7 Z. Hundert, Projekt organizacji i finansowania ,Wojska JKM i Rzptej Zaporoskiego” z 1683 roku, „Saeculum Christianum” 2016, t. 23, s. 315-322; idem, Organizacja husarii koronnej na kampanię wiedeńska 1683 roku [w:] „W hetmańskim trudzie”. Księga pamiątkowa ku czci Jana Wimmera, red. Z. Hundert, M. Wagner, Oświęcim 2017, s. 166-196. 
zamierzonego celu publikacja młodego historyka o wielce obiecującym tytule, czyli o „wojnie roku 1683 opisanej na nowo".

Bardziej interesująca jest próba nowego spojrzenia na działania wojenne na Podolu i w Mołdawii w latach 1683-1684, opublikowana stosunkowo niedawno przez innego młodego polskiego historyka9 .

Dość niekorzystnie natomiast przedstawia się sytuacja literatury historycznej dotyczącej naukowego poznania kolejnego etapu zmagań zbrojnych, w latach 16841696 (1699), mamy bowiem opracowania zaledwie kilku wybranych kampanii wojennych. Opisana została kampania żwaniecka 1684 roku $^{10}$, podobnie jak wyprawa bukowińska roku $1685^{11}$, a kampanię mołdawską 1686 roku Jana III opisano jeszcze przed wojną ${ }^{12}$. Kampanie kamienieckie z lat 1687 i 1688 znalazły analizę w kolejnych artykułach ${ }^{13}$.

Warto dodać, że jedynie kampania mołdawska 1686 roku uzyskała dodatkowe uzupełnienie w postaci dwóch artykułów, dotyczących organizacji komputowych jednostek wojska koronnego ${ }^{14}$.

Dla okresu po 1687 roku widoczna jest wyraźna luka w zainteresowaniach naszych badaczy - więc następne kampanie wojenne (zwane kamienieckimi) z lat 1688 i 1689 nadal oczekują na pogłębione studia historyczno-wojskowe. W 2016 roku ukazał się artykuł o kampanii mołdawskiej roku $1690^{15}$, w 2015 roku wyszła drukiem zapomniana praca, pochodząca z 1948 roku i dotycząca opisu i analizy kampanii mołdawskiej Jana III Sobieskiego w roku $1691^{16}$.

8 A. Witkowicz, Czerwone sztandary Osmanów. Wojna roku 1683 opisana na nowo, Warszawa 2016.

9 M. Markowicz, Daleko od Wiednia - działania militarne na podolsko-mołdawskim teatrze wojennym na przetomie 1683 i 1684 r., „Studia Historyczno-Wojskowe” 2015, t. VI, s. 91-108.

10 M. Wagner, Kampania żwaniecka 1684 roku, Warszawa 2013.

11 W. Wasilewski, Wyprawa bukowińska Stanisława Jabłonowskiego w 1685 roku, Warszawa 2002.

12 C. Chowaniec, Wyprawa Sobieskiego do Mołdawii w 1686 roku, Oświęcim 2015 (na podstawie wydania z 1931 r.).

13 J. Maroń, Kilka uwag o niefortunnej kampanii 1687 r. [w:] Ślask, Polska, Niemcy, [red. K. Matwijowski, W. Wrzesiński], Acta Universitatis Wratislaviensis. Historia, nr 74, Wrocław 1990, s. 97 104; M. Wagner, Kampania kamieniecka 1687 roku [w:] Hortus bellicus. Studia z dziejów wojskowości nowożytnej. Prace ofiarowane profesorowi Mirosławowi Nagielskiemu, red. K. Bobiatyński [et al.], Biblioteka Epoki Nowożytnej, t. 5, Warszawa 2017, s. 467-486; idem, Kampania kamieniecka 1688 roku [w:] Jarzmo Ligi Świętej? Jan III Sobieski i Rzeczpospolita w latach 1684-1696, red. D. Milewski, Warszawa 2017, s. 187-214.

14 Z. Hundert, Komput wojska koronnego na potrzeby podzialu hiberny w 1686 roku [w:] Studia nad staropolska sztuka wojenna, t. V, red. Z. Hundert, K. Żojdź, J.J. Sowa, Oświęcim 2017, s. 314-321; idem, Komputowe oddziały rodziny królewskiej w kampanii mołdawskiej 1686 roku w świetle rozkazów i sprawozdania sejmowego hetmana wielkiego koronnego Stanisława Jana Jabłonowskiego [w:] Jarzmo Ligi Świętej..., s. 161-186.

15 M. Wagner, Kampania mołdawska 1690 roku [w:] Na wojnie i w szlacheckim dworku. Studia i materiaty, [red. K. Maksymiuk, D. Wereda, R. Roguski], Siedlce 2016, s. 89-106.

16 P. Smolarek, Kampania moldawska Jana III roku 1691, do druku przygotowali Z. Hundert, M. Wagner, Oświęcim 2015 (na podstawie pracy magisterskiej z 1948 r.). 
Kolejny etap zmagań polsko-tureckich w latach 1692-1696 (1699) nadal oczekuje na zainteresowanie polskich badaczy. Warto przypomnieć, że były to lata dość istotne dla ówczesnej wojskowości polskiej i litewskiej. W tym właśnie okresie, przez zbudowanie sieci fortów, z Okopami Świętej Trójcy na czele, także w północnej Mołdawii, podjęto blokadę tureckiego Kamieńca Podolskiego, co przyniosło kilka taktycznych zwycięstw nad siłami tureckimi i tatarskimi (m.in. w latach 1692, 1694, 1695).

Ostatnio interesowano się zwycięskim starciem pod Hodowem w 1694 roku $^{17}$ i znaczeniem polskich fortów w Mołdawii w latach 1692-1696 ${ }^{18}$, lecz już opis działań obronnych we Lwowie w 1695 roku niewątpliwie wymaga nowego spojrzenia i wykorzystania uzupełniających materiałów źródłowych ${ }^{19}$.

Stan badań nad kolejnymi działaniami zbrojnymi w latach 1696-1699 oceniam mniej pozytywnie - jedynie kampania podhajecka doczekała się, w 1967 roku, analizy historyczno-wojskowej ${ }^{20}$. Wiele bardzo interesujących ustaleń przyniosła publikacja w 2003 roku artykułów dotyczących zakończenia w 1699 roku wojny Ligi Świętej z Imperium Osmańskim ${ }^{21}$. Trzeba także dodać, że w ostatnich latach został opisany najazd czambułów tatarskich w 1699 roku na ziemie polskie, wraz z analizą dokonanych tu zniszczeń22.

Ogólne opisy wspomnianych działań wojennych odnajdziemy w dawnych publikacjach $^{23}$, toteż zachęcam historyków do opracowania syntezy wojny polsko-tureckiej w latach 1684-1699, ukazanej na rozległym tle wydarzeń politycznych i militarnych w państwach Ligi Świętej zmagających się z siłami tureckimi.

Z przykrością konstatuję, że po 1983 roku nie ukazała się żadna nowa naukowa monografia na temat sztuki dowódczej hetmana i króla Jana III Sobieskiego. Niewątpliwie zasługującą na odrębne omówienie, interesującą próbę w tym względzie zaprezentował nam w 2009 roku Tadeusz Górski ${ }^{24}$.

Przechodząc do dorobku historiografii w zakresie historii wojska polskiego i litewskiego, zatem organizacji sił zbrojnych Rzeczypospolitej w czasach Jana III Sobieskiego, należy stwierdzić, że można go ocenić w miarę pozytywne - dysponujemy klasyczną już monografią Jana Wimmera na temat koronnych sił zbrojnych, jak również obszernym artykułem Andrzeja Rachuby na temat wojskowości litewskiej

17 M. Nagielski, Hodów 1694-2014. Ostatnie zwycięstwo husarii w wielkim stylu, „Kwartalnik Bellona" 2015, nr 1, s. 229-233.

18 M. Markowicz, Rola polskich załóg w twierdzach pótnocnej Mołdawii w systemie obrony pogranicza Rzeczypospolitej w latach 1692-1696 [w:] Jarzmo Ligi Świętej..., s. 215-232.

19 W. Majewski, Najazd Tatarów w lutym 1695 r., „Studia i Materiały do Historii Wojskowości” 1963 , t. IX, s. 125-178.

20 J. Wojtasik, Ostatnia rozprawa zbrojna z Turkami i Tatarami w 1698 roku, „Studia i Materiały do Historii Wojskowości” 1967, t. XIII, cz. 1, s. 63-127, cz. 2, s. 111-183; idem, Podhajce 1698, Warszawa 1990.

${ }_{21}$ Traktaty karłowickie z 1699 roku i ich nastepstwa, red. I. Czamańska, W. Szulc, Poznań 2003.

22 A. Gliwa, Ostatni napad tatarski na ziemię przemyska z 1699 r., „Studia Historyczne” 2000, R. XLIII, s. 569-591.

23 Np. M. Wagner, Stanisław Jabłonowski (1634-1702). Polityk i dowódca, t. I-II, Siedlce 1997.

24 T. Górski, Jan III Sobieski jako wódz, „Teki Gdańskie” 2008-2009, t. 10-11, s. 85-122. 
w XVII wieku ${ }^{25}$. Nadal jednak nie powstała pełna i rzetelna synteza dotycząca wojska polskiego w omawianym okresie; kilku artykułów doczekały się tylko lata „pokojowe" 1677-1679 - są to prace o charakterze przyczynkarskim, między innymi o sytuacji armii koronnej w latach $1677-1678^{26}$. Brakuje rzetelnych studiów o kondycji sił zbrojnych w końcowym okresie panowania Jana III Sobieskiego.

Pomimo sporego już zainteresowania dziejami kawalerii polskiej w drugiej połowie XVII wieku nie doczekaliśmy się naukowej syntezy poświęconej tego rodzaju wojskom ówczesnej Rzeczypospolitej. Ostatnie próby młodych badaczy pozostawiają wiele do życzenia, głównie z powodu braku warsztatu historyczno-wojskowego i niewykorzystania źródeł rękopiśmiennych. Wystarczy zatem wspomnieć nieudaną monografię jazdy polskiej w czasach Wazów ${ }^{27}$, również podobne syntezy na temat husarii ${ }^{28}$ czy jazdy kozackiej ${ }^{29}$.

$\mathrm{Na}$ tym tle rzetelnie prezentują się monografie i artykuły dotyczące husarii koronnej w latach $1672-1676^{30}$ czy chorągwi lekkich w drugiej połowie XVII wie$\mathrm{ku}^{31}$. Na podkreślenie zasługuje tutaj zwłaszcza dorobek Zbigniewa Hunderta, który opracował ważne artykuły poświęcone chorągwiom husarskim, a także formacjom petyhorskim w czasach Sobieskiego ${ }^{32}$. Z zainteresowaniem też obserwuję próby dokonania syntezy historii jazdy polskiej w latach $1683-1696^{33}$ czy dziejów niektórych

25 J. Wimmer, Wojsko polskie..., 1965 i 2013; A. Rachuba, Sity zbrojne Wielkiego Księstwa Litewskiego w XVII wieku, „Przegląd Wschodni” 1994, t. III, s. 379-410.

26 M. Wagner, Armia koronna w latach 1677-1678 [w:] Król Jan III Sobieski i Rzeczpospolita w latach 1674-1683, red. D. Milewski, Warszawa 2016, s. 177-200; Z. Hundert, Wykaz repartycji jednostek wojska koronnego, zgodnie z podziatem komisji lwowskiej w 1679 roku, „Przegląd Historyczno-Wojskowy" 2016, R. XVII, s. 17-34; idem, Wykaz koronnych choragwi i regimentów w okresie $1 \mathrm{~V}$ 1679-30 IV 1683. Przyczynek do organizacji wojska koronnego $w$ dobie pokoju 1677-1683, „Studia Historyczno-Wojskowe" 2015, t. V, s. 274-287.

27 M. Hubka, Jazda polska doby Wazów. Organizacja, uzbrojenie, taktyka, Piotrków Trybunalski 2007.

28 R. Sikora, Husaria pod Wiedniem 1683, Warszawa 2012; idem, Fenomen husarii, Warszawa 2013.

29 B. Głubisz, Jazda kozacka w armii koronnej 1549-1696, Poznań 2016.

30 Z. Hundert, Husaria koronna w wojnie polsko-tureckiej 1672-1676, Oświęcim 2012.

31 M. Kosowski, Choragwie woloskie w wojsku koronnym w II połowie XVII wieku, Wojownicy, t. 3, Zabrze 2009.

32 Z. Hundert, Choragiew husarska Jana Sobieskiego w latach 1673-1676 [w:] Spes in virtute, salus in victoria. Materiały z „IX Ogólnopolskiej Konferencji Studentów Historyków Wojskowości”, Lublin 8-10 grudnia 2011, red. J. Gładysz, D. Lipska, A. Głady sz, Lublin-Zabrze 2013, s. 115-136; idem, ,,Kopijników, czyli husarzy choragwie, owa nieodparta $w$ wojnie potęga, powinny być pomnożone" - Hetman Jan Sobieski a husaria koronna w latach 1667-1673 [w:] Marszatek i hetman koronny Jan Sobieski, red. D. Milewski, Warszawa 2014, s. 247-272; idem, Husaria pod Chocimiem w 1673 roku [w:] Człowiek i wojna. Z dziejów wojskowości polskiej i powszechnej, red. A. Niewiński, Homo Militans, t. 1, Oświęcim 2013, s. 79-90; idem, Choragiew jazdy hospodara multańskiego (wołoskiego) Konstantego Şerbana w wojsku koronnym w latach 1673-1676, „Studia Orientale” 2012, nr 1, s. 191-210; idem, Kilka uwag na temat choragwi petyhorskich w wojskach Rzeczypospolitej w latach 1673-1683 [w:] W pancerzu przez wieki. Z dziejów wojskowości polskiej i powszechnej, red. M. Baranowski, A. Gładysz, A. Niewiński, Oświęcim 2014, s. 136-149.

33 M. Wagner, Kawaleria koronna w dobie panowania Jana III Sobieskiego. Lata 1683-1696 [w:] Do szarży marsz, marsz... Studia z dziejów kawalerii, red. A. Smoliński, t. 3, Torun 2012, s. 67-112. 
jednostek wojskowych z lat 90. XVII wieku, a także ich udziału w walkach z siłami Imperium Osmańskiego ${ }^{34}$.

Jeżeli powyższy wykaz uzupełnimy artykułem o organizacji arkabuzerii koronnej w XVII wieku ${ }^{35}$, to dotychczasowe rozważania prowadzą do oczywistego wniosku, że należy obecnie podjąć wysiłki w celu opracowania w niedalekiej przyszłości obszernej i pełnej syntezy dotyczącej tego rodzaju wojska - jazdy koronnej i litewskiej w czasach Jana III Sobieskiego.

O wiele korzystniej przedstawia się sytuacja stanu badań nad dziejami piechoty i dragonii koronnej - dysponujemy bowiem znakomitą monografią tego rodzaju sił zbrojnych autorstwa Jana Wimmera z 1978 roku $^{36}$ - ale już dragonia (ulubiona przecież formacja Jana III Sobieskiego) nie ma naukowej syntezy ${ }^{37}$. A ta ostatnia zasługuje na szczególną uwagę polskich badaczy, ponieważ właśnie w tym okresie dragonia europejska przekształca się z formacji pieszych w konne, gdy tymczasem polskie jednostki praktycznie znikają z sił zbrojnych dawnej Rzeczypospolitej ${ }^{38}$.

Widoczne są szczególne zaniedbania w odniesieniu do dziejów artylerii w czasach Jana III Sobieskiego - pomimo zgromadzenia w kraju wielu zasobów rękopiśmiennych, między innymi w Krakowie, Warszawie i Wrocławiu, gdzie znajdują się fragmenty archiwum korpusu artylerii koronnej, nie wspominając o zasobach zagranicznych. Kilka drobnych artykułów o charakterze przyczynkarskim nie wypełnia dotkliwej luki, toteż uważam, że jest to szczególnie pilne zadanie badawcze stojące przed następnym pokoleniem naszych historyków.

Niezbyt wiele wiemy także na temat funkcjonowania inżynierii wojskowej w czasach Jana III Sobieskiego, dlatego problem ten wymaga pogłębionych badań naukowych, tym bardziej że zostały poczynione $\mathrm{w}$ tym zakresie pewne próby, których rezultatem są wybrane monografie i artykuły naukowe ${ }^{39}$. Nie podejmowały one jednak interesującej nas problematyki w odniesieniu do czasów Sobieskiego, jedynym

34 J.J. Sowa, Ludzie niezwalczeni. Rejestry choragwi jazdy autoramentu narodowego w Okopach Świętej Trójcy 1693-1695 [w:] Studia nad staropolska sztukq wojenna, t. II, red. Z. Hundert, Oświęcim 2013, s. 259-299; idem, Jednostki komputowe Adama Mikołaja Sieniawskiego do 1702 r., cz. 1: Udziat $w$ działaniach wojennych do 1696 roku [w:] Studia nad staropolska sztuka wojenna, t. IV, red. Z. Hundert, K. Żojdź, J.J. Sow a, Oświęcim 2015, s. 209-221, cz. 2 [w:] Studia nad staropolska sztuka..., t. V, s. $247-264$.

35 M. Nagielski, Organizacja rajtarii i arkabuzerii koronnej w XVII wieku [w:] Organizacja armii w nowożytnej Europie. Struktura - urzędy - prawo - finanse, red. K. Łopatecki, Zabrze 2011, s. $197-216$.

36 J. Wimmer, Historia piechoty polskiej do roku 1864, Warszawa 1978.

37 Wiadomo mi, że w Instytucie Historycznym Uniwersytetu Warszawskiego przygotowywana jest monografia na temat dziejów polskich formacji dragońskich w XVII-XVIII w.

38 M. Wagner, Formacje dragońskie armii koronnej w czasach Jana III Sobieskiego. Lata 16671696 [w:] Do szarży marsz, marsz..., t. 5, Torun 2014, s. 105-146; idem, Frejkompania dragońska artylerii koronnej w końcu XVII wieku. Z dziejów modernizacji wojska polskiego w dobie Jana III Sobieskiego [w:] Modernizacja życia społeczno-gospodarczego i politycznego na ziemiach polskich, red. J. Cabaj, K. Maksymiuk, D. Wereda, Siedlce 2017, s. 23-34.

39 Zob. B. Dybaś, Fortece Rzeczypospolitej. Studium z dziejów budowy fortyfikacji stalych w państwie polsko-litewskim w XVII wieku, Torun 1998; Zamki, twierdze i garnizony Opola, Ślaska i dawnej Rzeczypospolitej, red. T. Ciesielski, Zabrze 2010. 
wyjątkiem jest artykuł Zbigniewa Hunderta o garnizonie Kamieńca Podolskiego w latach $1667-1672^{40}$.

Podobnie jak problematyka garnizonów wojskowych również zagadnienie funkcjonowania arsenałów (królewskich, miejskich i prywatnych) nie znalazło większego zainteresowania wśród historyków czasów Sobieskiego. O wiele lepiej prezentuje się dorobek badaczy w odniesieniu do dziejów cekhauzów i zbrojowni magnackich ${ }^{41}$, lecz już tak ważne z punktu widzenia gromadzenia i magazynowania broni arsenały królewskie w Warszawie i we Lwowie jeszcze nie doczekały się monografii naukowych. Szczególnie dotkliwy jest tutaj brak monografii arsenału warszawskiego, pełniącego w czasach Sobieskiego znaczące funkcje wojskowe i ceremonialne. Nie mniej istotny jest jednak także arsenał lwowski, który od lat 70. odgrywał rolę głównej bazy koronnej artylerii podczas długotrwałych zmagań zbrojnych z Imperium Osmańskim.

Po studiach Mirosława Nagielskiego o organizacji oraz liczebności gwardii królewskich za panowania dwóch ostatnich Wazów należy podjąć badania i przygotować syntetyczne opracowanie na temat regimentów (komputowych i nadwornych) króla Jana III Sobieskiego. Problematyka taka ma rozpoznaną bazę dokumentacyjną, wypracowane wzory można zaś zastosować również przy zidentyfikowaniu i opracowaniu wymienionego tutaj zagadnienia badawczego ${ }^{42}$.

$\mathrm{Z}$ zadowoleniem odnotowuję zainteresowanie historyków wybranymi rodzajami służb wojskowych, takimi jak sądownictwo wojskowe ${ }^{43}$, jednak już między innymi problematyka finansowania armii koronnej, wojskowej służby zdrowia i logistyki wojskowej z czasów Jana III Sobieskiego nadal oczekują na swego historyka. W kwestii finansowania wojska nie wypełniają luki przyczynkarskie szkice dotyczące struktury wydatków skarbu hetmana wielkiego Stanisława Jabłonowskiego na potrzeby wojska polskiego w latach $1685-1689^{44}$, ale godny odnotowania jest rzetelny

40 Z. Hundert, Garnizon wojskowy Kamieńca Podolskiego w latach 1667-1672 - zarys problematyki, „Saeculum Christianum” 2014, t. 21, s. 141-153.

${ }_{41}$ P.S. Szlezynger, Inwentarze cekhauzów $i$ armaty zamkowej $w$ XVII $i$ XVIII wieku $w$ magnackich fortecach w Wiśniczu, Połonnem, Dubnem i Żótkwi, „Studia i Materiały do Historii Wojskowości” 2003, t. XL, s. 283-330; M. Sawicki, Twierdza radziwillowska w Birżach w XVII wieku. Artyleria i cekhauz [w:] Wśród dymu i ognia. Studia z dziejów artylerii, t. 2, red. A. Smoliński, Torun 2016, s. 13-35; idem, Artyleria i cekhauz twierdzy Lachowicze w 1658 roku [w:] Людзі і ўлада Навагрудчыны: гісторыя уззаемадзеяння (да 500-годдзя надання Навагрудку прывілея на магдэбургскае права), уклад. А.А. Скеп'ян, В.В. Даніловіч, А.Б. Доўнар, рэд. А.А. Каваленя [et al.], Мінск 2013, s. 191-201; idem, Artyleria i cekhauz smoleński w 1654 roku [w:] Organizacja armii w nowożytnej Europie..., s. 313-322.

42 Według mojej wiedzy w Instytucie Nauk Historycznych Uniwersytetu Kardynała Stefana Wyszyńskiego powstaje monografia na temat formacji gwardii królewskiej Jana III Sobieskiego.

43 J.J. Sowa, ,, W czym veritur powaga moja hetmańska ...”. Organizacja i procedura sadu hetmańskiego w Koronie w latach 1683-1699, „Czasopismo Prawno-Historyczne” 2013, t. 65, z. 1, s. 203-228. Autor tego nowatorskiego artykułu przygotowuje rozprawę doktorską na temat funkcjonowania sądownictwa wojskowego w końcu XVII w.

44 M. Wagner, Wydatki wojskowe hetmana wielkiego koronnego Stanistawa Jabłonowskiego w latach 1685-1689 [w:] Pecunia nervus belli. Z dziejów dyplomacji i stosunków międzynarodowych $w X V-X V I I I$ wieku, red. M. Markiewicz, R. Skowron, F. Wolański, Prace Naukowe Uniwersytetu 
artykuł na temat hiberny i jej udziału w finansowaniu wojsk koronnych w latach $1685-1700^{45}$.

W odniesieniu do pozostałych rodzajów sił zbrojnych dysponujemy pracą omawiającą oddziały pospolitego ruszenia ${ }^{46}$ oraz syntezą dotyczącą wojsk powiatowych ${ }^{47}$, nadal natomiast czeka na opracowanie problematyka wojsk prywatnych i nadwornych, niezwykle istotna dla poznania ogólnej kondycji sił zbrojnych w Rzeczypospolitej Jana III Sobieskiego ${ }^{48}$. Ciekawa jest próba charakterystyki polskich formacji nieregularnych czy ochotniczych w wojnie tureckiej w latach $1672-1676^{49}$. W zakresie badań nad dziejami sił powiatowych opublikowano dwa nowe szkice - o formacjach zbrojnych utworzonych w województwach wielkopolskich ${ }^{50}$ oraz w ziemi warszawskiej w latach 1671-1673 ${ }^{51}$. Zbigniew Hundert pisał również o wojskach ordynackich w latach $1674-1676^{52}$ oraz o wojskach prywatnych rodziny Radziwiłłów w latach 1669-169653.

$\mathrm{Z}$ zainteresowaniem obserwuję rosnące zaangażowanie młodych historyków w badanie dziejów wojskowości litewskiej w drugiej połowie XVII wieku, a zatem w czasach Jana III Sobieskiego. Nie sposób więc pominąć dwóch znakomitych biografii dowódców wojsk Wielkiego Księstwa - hetmana Michała Kazimierza $\mathrm{Paca}^{54}$ i regimentarza Aleksandra Hilarego Połubińskiego ${ }^{55}$, a także kilku artykułów

Śląskiego w Katowicach, nr 3448, Katowice 2016, s. 226-238; idem, ,Sprawy mołdawskie” w rachunkach hetmana wielkiego koronnego Stanisława Jabłonowskiego w latach 1685-1689 [w:] Ze wspólnej przeszłości. Studia z dziejów stosunków polsko-rumuńskich, red. A. Smoliński, Torun 2017, s. 11-23; idem, ,, Sprawy kozackie” w rachunkach hetmana wielkiego Stanisława Jablonowskiego w latach 16851689 [w:] Wczesnonowożytny człowiek. Przestrzeń - władza - prawo w XVI-XVIII wieku, red. W. Michałowski, J. Stolicki, Patrimonium, t. 1, Kijów-Kraków 2015, s. 328-338.

45 J.J. Sowa, Nervus belli czy finansowe jarzmo Ligi Świętej Skarb hibernowy a finansowanie wysitku wojennego Korony 1685-1700 [w:] Jarzmo Ligi Świętej..., s. 137-160.

46 L.A. Wierzbicki, Pospolite ruszenie w Polsce $w$ drugiej potowie XVII wieku. Ostatnie wyprawy z lat 1670-1672, Lublin 2011.

47 D. Kupisz, Wojska powiatowe samorząów Małopolski i Rusi Czerwonej w latach 1572-1717, Lublin 2008.

48 Mam informację o przygotowywanej w Instytucie Historii i Stosunków Międzynarodowych Uniwersytetu Przyrodniczo-Humanistycznego w Siedlcach rozprawie doktorskiej o wojskach ordynackich w XVII w.

49 M. Wagner, „Inna wojna Sobieskiego”. Polskie formacje nieregularne i ochotnicze $w$ wojnie polsko-tureckiej (1672-1676) [w:] Studia z dziejów Wielkiego Księstwa Litewskiego (XVI-XVIII wieku), red. S. Górzyński, M. Nagielski, Warszawa 2014, s. 435-446.

50 Z. Hundert, Powiatowe choragwie kozackie (pancerne) województw poznańskiego i kaliskiego w latach 1671-1673 [w:] Do szarży marsz, marsz ..., t. 6, Torun 2015, s. 63-106.

51 Idem, Wojska zaciagnięte przez samorzad lokalny ziemi warszawskiej w latach 1671-1673, „Almanach Warszawy” 2015, t. 9, s. 71-106.

52 Idem, Sity ordynacji zamojskiej w latach 1674-1676 - przyczynek do badań nad funkcjonowaniem wojsk ordynacji rodowych w XVII wieku [w:] Studia nad staropolska sztuka ..., t. IV, s. 198-208.

53 Idem, Oddzialy Radziwiltów w wojsku koronnym w dobie panowania „królów rodaków” (16691696) [w:] Radziwillowie w stużbie Marsa, red. M. Nagielski, K. Żojdź, Warszawa 2017, s. 257-279.

${ }^{54}$ K. Bobiatyński, Michat Kazimierz Pac, wojewoda wileński, hetman wielki litewski. Działalność polityczno-wojskowa, Warszawa 2008.

55 A.A. Majewski, Aleksander Hilary Polubiński (1626-1679), marszatek wielki litewski. Działalność polityczno-wojskowa, Prace Instytutu Historycznego Uniwersytetu Warszawskiego, Warszawa 2017. 
o hetmanie litewskim Michale Kazimierzu Radziwille ${ }^{56}$. Interesujące są również artykuły na temat roli wojska w życiu publicznym Wielkiego Księstwa ${ }^{57}$ oraz fragmentu dziejów artylerii litewskiej w końcu XVII wieku ${ }^{58}$ czy jazdy litewskiej w omawianym okresie ${ }^{59}$, a także wojska litewskiego w kampanii 1673 roku $^{60}$.

Mimo znacznego postępu w badaniach nad wojskowością kozacką w tym czasie takie wybrane zagadnienia jak relacje króla Jana III Sobieskiego z hetmanami kozackimi i starszyzną czy rzeczywisty wpływ tego monarchy na postawy i poczynania pułkowników kozackich nie są jeszcze dostatecznie zbadane. Zachęcam do dokonania rzetelnej i naukowej syntezy ówczesnych stosunków polsko-kozackich, $\mathrm{z}$ uwzględnieniem na przykład zagadnienia udziału pułków kozackich w licznych wyprawach do Mołdawii oraz na Budżak i w walkach z Tatarami w latach 80. i 90. XVII wieku ${ }^{61}$.

Nadal pozostaje do uzupełnienia problematyka konfederacji wojskowych w czasach Jana III Sobieskiego. Brakuje opracowania projektów organizacji związków w wojsku koronnym i litewskim w latach 90., a zwłaszcza prób zawiązania konfederacji w 1694 roku czy jej zorganizowania w latach 1696-1697. Przede wszystkim jednak brakuje rzetelnej pracy odpowiadającej na zasadnicze pytanie, dlaczego w czasach Sobieskiego nie doszło do zorganizowania konfederacji wojskowej na miarę tych z czasów jego poprzedników.

56 Zob. A. Rachuba, Doświadczenia wojskowe hetmana Michała Kazimierza Radziwitla (16351680); K. Bobiatyński, Michat Kazimierz Radziwitt jako hetman polny litewski (1668-1680) [w:] Radziwitlowie w stużbie Marsa..., s. 221-228 i 229-243.

57 K. Bobiatyński, Armia jako oręż hetmanów w polityce wewnętrznej w Wielkim Księstwie Litewskim w II połowie XVII wieku (lata 1654-1682) - wybrane zagadnienia, „Studia Historyczno-Wojskowe” 2009, t. III, s. 151-162; idem, Wojsko i polityka - kilka uwag o udziale armii litewskiej w kampaniach przeciw Turkom i Tatarom w latach 70. XVII wieku [w:] Rzeczpospolita państwem wielu narodowości $i$ wyznań, red. T. Ciesielski, A. Filipczak-Kocur, Warszawa-Opole 2008, s. 503-511; idem, Rola wojska $w$ życiu publicznym $w$ Wielkim Księstwie Litewskim $w$ okresie tzw. hegemonii pacowskiej (16661682) [w:] Spoleczeństwo a wojsko, [red. I.M. Dacka-Górzyńska, A. Karpiński, M. Nagielski], Społeczeństwo Staropolskie. Seria Nowa, t. IV, Warszawa 2015, s. 167-188.

58 M. Sawicki, Artyleria litewska w latach osiemdziesiatych XVII wieku. Organizacja i finansowanie [w:] Artyleria polska. Historia - teraźniejszość - przyszłość (myśl wojskowa, szkolnictwo artyleryjskie, technika i uzbrojenie). Materiaty pokonferencyjne, III konferencja naukowa, Toruń 11 maja 2009 r. Sympozjum naukowe, Toruń 4 grudnia 2009 r., kom. red. M. Giętkowski, J. Ślipiec, Toruń 2009, s. $161-174$.

59 Idem, Choragwie sapieżyńskie $w$ drugiej połowie XVII wieku w świetle ksiag litewskich komisji skarbowo-wojskowych [w:] Вялікае Княства Літоўскае: палітыка, эканоміка, культура: зборнік навуковых артыкулай: у дзвюх частках, Ч. 1, уклад. А.А. Скеп’ян, рэд. У.Р. Гусакоў [et al.], Мінск 2017, s. 409-418; idem, Choragwie radziwiltowskie w II polowie XVII w. w świetle ksiag litewskich komisji skarbowo-wojskowych [w:] Radziwiłlowie w stużbie Marsa..., s. 243-256.

${ }^{60}$ K. Bobiatyński, $W$ drodze pod Chocim. Litewskie przygotowania do wojny przeciw Turkom w 1673 r. [w:] Studia z dziejów Wielkiego Księstwa Litewskiego..., s. 27-47.

${ }_{61}$ Zob. P. Kroll, Jan III Sobieski wobec Kozaczyzny w latach 1676-1683 [w:] Król Jan III Sobieski i Rzeczpospolita..., s. 201-226; idem, Hetmanat lewobrzeżny wobec Rzeczypospolitej i Prawobrzeża $w$ dobie Ligi Świętej [w:] Jarzmo Ligi Świętej..., s. 113-136; D. Milew ski, Wojenne interludium. Stosunki polsko-mołdawskie w latach 1676-1683 [w:] Król Jan III Sobieski i Rzeczpospolita..., s. 227-256. 
$\mathrm{Z}$ zadowoleniem przyjmuję natomiast pogłębienie badań historycznych nad zagadnieniem patronatu wojskowego, tak znakomicie opracowanym dla pierwszej połowy XVII wieku, w wymiarze koronnym i litewskim. Bardzo dobrym przykładem rzetelnej monografii naukowej jest najnowsza praca Zbigniewa Hunderta o roli wojska koronnego w życiu publicznym państwa w latach $1669-1673^{62}$, a także tego autora na temat stanowiska Jana III wobec wojska koronnego po 1674 roku $^{63}$.

Zbigniew Hundert słusznie zajął się problematyką udziału armii koronnej w obu elekcjach - Michała Korybuta ${ }^{64}$ i Jana III Sobieskiego ${ }^{65}$, podkreślając rzeczywisty wpływ wojska polskiego na wybór tego ostatniego elekta. Tenże autor omówił również związki ówczesnych sił zbrojnych z ziemskimi gremiami szlacheckimi na obszarze Korony ${ }^{66}$.

Tymczasem biografistyka wojskowa dotycząca czasów Jana Sobieskiego pozostawia jeszcze wiele do życzenia, jedynie problem prozopografii został zidentyfikowany i zanalizowany w ostatnich latach - zarówno w postaci monografii naukowej, jak i słownika biograficznego ${ }^{67}$.

Posiadamy biografie hetmanów koronnych i litewskich ${ }^{68}$, nadto generałów artylerii koronne ${ }^{69} \mathrm{i}$ dowódców kozackich ${ }^{70}$, ale jednak nadal oczekujemy na rzetelne i naukowe syntezy na temat poszczególnych hetmanów koronnych, między innymi Wiśniowieckich, Sieniawskich oraz Lanckorońskich ${ }^{71}$, zwłaszcza wielce zasłużonego generała artylerii koronnej Marcina Kątskiego. Dotychczasowe bowiem dokonania

62 Z. Hundert, Między buława a tronem. Wojsko koronne $w$ walce stronnictwa malkontentów $z$ ugrupowaniem dworskim w latach 1669-1673, Oświęcim 2014.

${ }^{63}$ Idem, Pozycja Jana III w wojsku koronnym w latach 1674-1683. Utrzymanie czy też utrata wptywów wypracowanych w czasie sprawowania godności hetmańskiej? [w:] Król Jan III Sobieski i Rzeczpospolita..., s. 121-151.

64 Idem, Wojsko koronne wobec elekcji 1669 roku, „Studia z Dziejów Wojskowości” 2014, t. 3, s. $91-114$.

${ }^{65}$ Idem, Wojsko koronne a elekcja 1674 roku [w:] Wokót wolnych elekcji w państwie polsko-litewskim XVI-XVIII wieku. O znaczeniu idei wyboru - między prawami a obowiązkami, red. M. Markiewicz, D. Rolnik, F. Wolański, Katowice 2016, s. 308-332.

${ }^{66}$ Idem, Zwiazki szlachty województwa mazowieckiego $z$ wojskiem $w$ dobie panowania Jana III Sobieskiego - wybrane przyktady [w:] Spoteczeństwo polskie i wojsko. Studia i materiaty, [red. K. Maksymiuk, D. Wereda, A. Zawadzki], Siedlce 2016, s. 83-98; idem, Szlachta ziemi liwskiej wobec wojska koronnego $w$ latach 1667-1673 w świetle akt sejmikowych, „Studia Mazowieckie” 2017, t. 12 (26), nr 2, s. 13-31.

67 M. Wagner, Korpus oficerski wojska polskiego w drugiej połowie XVII wieku, Oświęcim 2015; idem, Stownik biograficzny oficerów polskich drugiej połowy XVII wieku, t. I-III, Oświęcim 2013, 2014, 2018.

68 Zob. drugie, poprawione i uzupełnione wydania obu publikacji: Poczet hetmanów Rzeczypospolitej. Hetmani koronni, red. M. Nagielski, Warszawa 2005, i Poczet hetmanów Rzeczypospolitej. Hetmani litewscy, red. M. Nagielski, Warszawa 2006.

${ }_{69}$ Zob. cykl artykułów biograficznych Mirosława Nagielskiego opublikowanych w toruńskim czasopiśmie „Studia Artyleryjskie” 2011-2012, t. 2-4.

70 Zob. wydanie popularnonaukowe: Hetmani zaporoscy w stużbie króla i Rzeczypospolitej, red. P. Kroll, M. Nagielski, M. Wagner, Zabrze 2010.

71 Zob. Z. Chmiel, Udziat Lanckorońskich w wojnach prowadzonych przez Rzeczpospolita w okresie hetmaństwa Jana Sobieskiego [w:] Marszatek i hetman koronny..., s. 273-294. 
w tym zakresie nie są zadowalające - wprawdzie ukazała się w miarę pełna biografia generała $^{72}$, lecz na niskim poziomie naukowym, a również ostatni artykuł biograficzny $^{73}$ nie pretenduje do miana nowoczesnej biografii tego znakomitego szefa korpusu artylerii koronnej. Ten stan może dziwić, w archiwach i bibliotekach polskich i zagranicznych odnajdziemy bowiem bardzo bogate zasoby archiwaliów ilustrujących nie tylko fragmenty życia generała, ale również jego dokonania organizacyjne oraz bojowe jako dowódcy artylerii koronnej w dobie Sobieskiego.

Pozostaje jeszcze spora grupa wyższych dowódców wojskowych, na przykład regimentarzy czy generałów, których szczegółowe biografie mogłyby uściślić chociażby skład personalny czy mechanizmy funkcjonowania grup wojskowych, które wspierały poczynania polityczne Jana III Sobieskiego w latach 80. i 90. XVII wieku.

Dysponujemy zatem kilkoma rzetelnymi studiami biograficznymi dotyczącymi wyższych dowódców wojskowych - Władysława Wilczkowskiego ${ }^{74}$, Aleksandra Polanowskiego ${ }^{75}$, Jana Mikołaja Skrzetuskiego ${ }^{76}$, Nikodema Żaboklickiego ${ }^{77}$, Hieronima Lubomirskiego ${ }^{78}$, Baltazara Wilgi Godzimirskiego ${ }^{79}$, Jerzego Wołodyjowskiego ${ }^{80}$ oraz Jana Fryderyka von der Groebena ${ }^{81}$ i Jana Michała Żebrowskiego ${ }^{82}$. Ponadto ukazała się próba syntetycznego spojrzenia na środowisko generałów wojska polskiego w czasach Sobieskiego ${ }^{83}$.

72 P. Salamon, Marcin Kazimierz Kątski 1635-1710. Zarys biograficzny, Kraków 2013.

73 M. Nagielski, Marcin Kazimierz Kątski generat artylerii koronnej w stużbie króla i Rzeczypospolitej (1656-1710), „Studia Artyleryjskie” 2012, t. 4, s. 133-174.

74 Z. Hundert, Władysław Wilczkowski, porucznik husarski i putkownik królewski [w:] Na z góry upatrzonych pozycjach, red. B. Międzybrodzki [et al.], Warszawa-Zabrze 2011, s. 165-173.

75 Z. Hundert, Aleksander Polanowski - porucznik husarski i pułkownik Jego Królewskiej Miłości, „Studia z Dziejów Wojskowości” 2013, t. 2, s. 41-70.

76 Idem, Jak Mikołaj Skrzetuski zostat rotmistrzem pancernym, czyli kilka uwag o ostatnich latach stużby wojskowej pierwowzoru bohatera ,Trylogii” [w:] Studia nad staropolskq sztuka wojenna, t. III, red. Z. Hundert, K. Żojdź, J.J. Sowa, Oświęcim 2014, s. 133-141.

77 Z. Hundert, J.J. Sow a, Od towarzysza jazdy do wojewody podolskiego. Przebieg stużby wojskowej Nikodema Żaboklickiego w latach 1656-1706, „Res Historica” 2016, nr 42, s. 127-181.

78 Idem, Działalność wojskowa i polityczna Hieronima Augustyna Lubomirskiego w latach 1669 1673 - glosa do biografii [w:] Hortus bellicus..., s. 385-404.

79 M. Wagner, Baltazar Wilga Godzimirski - ostatni komisarz kozacki Rzeczypospolitej (1692_ 1699), „Zeszyty Naukowe Uniwersytetu Jagiellońskiego. Prace Historyczne” 2016, nr 2 (143): Ukraina, Ruś w epoce nowożytnej. Instytucje i elity, red. J. Stolicki, W. Michałow ski, s. 327-334.

${ }^{80}$ Idem, Jerzy Wolodyjowski (okoto 1620-1672) rotmistrz piechoty i stolnik przemyski [w:] ,, Whetmańskim trudzie”..., s. 152-165.

81 Idem, Jan Fryderyk von der Groeben (1645-1712) - generat wojska polskiego i dyplomata Jana III Sobieskiego [w:] Bezpieczeństwo - edukacja - wychowanie. Ksiega jubileuszowa dedykowana Profesorowi Jerzemu Kunikowskiemu, t. 1, red. T. Zacharuk, M. Minkina, B. Czeluścińska, Siedlce 2015, s. 355-360.

82 Idem, Zapomniany Hektor. Generat Jan Michat Żebrowski (około 1630-1676) [w:] Kadry decyduja o wszystkim. Studia z zakresu biografistyki wojskowej, red. J. Jędrysiak [et al.], Wrocławskie Studia z Historii Wojskowości, t. 4, Wrocław 2015, s. 219-236.

83 Idem, Generałowie wojska polskiego w spoleczeństwie Rzeczypospolitej czasów Jana III Sobieskiego (1668-1696) [w:] Społeczeństwo a wojsko..., s. 189-209. 
Edytorstwo źródeł historyczno-wojskowych dla czasów panowania Jana III $\mathrm{w}$ okresie powiedeńskim oceniam umiarkowanie ${ }^{84}, \mathrm{z}$ jednej strony bowiem dysponujemy już pewnym dorobkiem ${ }^{85}$, jednak z drugiej ułatwiony dostęp do zbiorów na przykład niemieckich, ukraińskich i białoruskich pozwala na zrealizowanie nowych wyzwań edytorskich. Niewątpliwie powinny one kontynuować dawne projekty naukowe podjęte niegdyś przez Janusza Wolińskiego czy Jana Wimmera - wybitnych badaczy wojskowości czasów Sobieskiego ${ }^{86}$.

Warto przy tej okazji odnotować zainteresowanie historyków publikacjami testamentów żołnierzy czynnych w drugiej połowie XVII wieku - prócz cyklu testamentów szlacheckich z Wielkopolski (1631-1700), opublikowanych przez Pawła Klinta, należy wymienić testamenty z ziemi halickiej ${ }^{87}$ oraz z Wołynia ${ }^{88}$, a także testamenty poszczególnych dowódców ${ }^{89}$. Ostatnio Jan Jerzy Sowa wydał kilka bardzo interesujących testamentów oficerów wojska polskiego z lat 80. XVII stulecia ${ }^{90}$.

Upominam się również o identyfikację i publikację inwentarzy ruchomości pozostałych po zmarłych wojskowych - a odnajdziemy tutaj między innymi dokument dotyczący Hektora Kamienieckiego - Jerzego Wołodyjowskiego z 1672 roku $^{91}$.

Na zakończenie kilka uwag podsumowujących - w pracach nad historią wojska, wojen i sztuki wojennej czy biografistyki w dobie Jana III Sobieskiego zdecydowanie dominuje ośrodek warszawski, skupiony w dwóch uczelniach (Uniwersytet Warszawski i Uniwersytet Kardynała Stefana Wyszyńskiego), z kilkoma historykami niezależnymi. $Z$ jednej strony taka centralizacja badań naukowych niewątpliwie sprzyja ich rozwojowi, ale $\mathrm{z}$ drugiej w sposób oczywisty zawęża grono badaczy

84 Idem, Perspektywy edycji nowożytnych źródeł historyczno-wojskowych z XVII-XVIII wieku [w:] Edytorstwo źródel - ograniczenia i perspektywy, red. A. Perłakowski, Kraków 2015, s. 69-90.

85 Idem, Źródła do dziejów wojny polsko-tureckiej w latach 1683-1699, Oświęcim 2016.

86 Zob. nowe publikacje M. Nagielskiego: Listy komendantów Białej Cerkwi Ottona Ernesta i Krzysztofa Rappe z lat 1681-1682, „Studia Historyczno-Wojskowe” 2006, t. I, s. 255-267; Listy z teatru działań przeciwko Turkom i Tatarom do Jana III Sobieskiego z Archiwum Historycznego Białorusi w Mińsku [w:] Państwo, demokracja, chłopi. Studia z historii społeczno-politycznej Polski (XVII-XX w.). Tom studiów dedykowany profesorowi Romualdowi Wacławowi Turkowskiemu z okazji 65-lecia urodzin i 40-lecia pracy dydaktyczno-naukowej, red. S.J. Pastuszka, J. Sztejnbis-Zdyb, Warszawa 2016, s. 507-521; Komputy wojska koronnego z 1689 roku jako źródto do składu, struktury i organizacji armii koronnej $w$ dobie panowania Jana III Sobieskiego [w:] Sic erat in votis. Studia i szkice ofiarowane Profesorowi Zbigniewowi Anusikowi w sześćdziesiątą rocznicę urodzin. Rzeczpospolita w czasach nowożytnych, red. M. Karkocha, P. Robak, Łódź 2017, s. 242-253.

87 P. Klint, Testamenty żolnierzy z Wielkopolski $i$ ziemi halickiej z XVII w., „Kwartalnik Historii Kultury Materialnej” 2016, t. 64, s. 197-210.

88 N. Biłous, Testamenty wojskowych poległych $i$ zmartych na Wolyniu $w$ XVII w., „Kwartalnik Historii Kultury Materialnej” 2016, t. 64, s. 211-224.

89 K. Bobiatyński, M. Nagielski, Testamenty Michała Kazimierza Paca i Aleksandra Hilarego Polubińskiego w przededniu kampanii na Ukrainie przeciwko Turkom i Tatarom w 1675 roku, „Materiały do Historii Wojskowości" 2006, nr 3, cz. 1, s. 125-155; A. Markiewicz, Testament rotmistrza Marcina Ubysza z Mogielnicy z 1690 roku, ,Rocznik Przemyski” 2012, t. 48, s. 21-32.

90 J.J. Sowa, „Dysponuję krwawa pracę moją”. Testamenty oficerów wojska koronnego z ksiag grodzkich lwowskich z lat 80. XVII wieku [w:] Hortus bellicus..., s. 583-605.

91 S. Życiński, Inwentarz pozostałości po Jerzym Wołhodyiowskim pułkowniku choragwi laudańskiej z roku 1672, „Zeszyt Naukowy Muzeum Wojska w Białymstoku” 1988, nr 12, s. 159-161. 
zajmujących się epoką Jana Sobieskiego i historią ówczesnej wojskowości. Trzeba dodać, że z punktu widzenia chronologii badań największa aktywność naukowców przypadła na lata $60 ., 70$. i 80 . XX wieku, a ponadto na pierwszą i drugą dekadę XXI stulecia, co bardzo dobrze rokuje dla przyszłości omawianych tutaj badań historycznych.

Oceniając perspektywy przywołanych badań historyczno-wojskowych, zauważam pilną konieczność opracowania syntezy dotyczącej wojny polsko-tureckiej w okresie powiedeńskim, a ponadto dziejów kawalerii polskiej i korpusu artylerii w drugiej połowie XVII wieku, przede wszystkim zaś sztuki dowódczej Jana III Sobieskiego, nie mówiąc już o realizacji nowych projektów edytorskich.

Widzę także potrzebę podjęcia prac naukowych na nowych polach badawczych, a pośrednio dotyczących badań historyczno-wojskowych doby Jana III Sobieskiego. Mogą to być takie zagadnienia, jak socjotopografia wojskowa, genealogia wojskowa, ceremoniał wojskowy czy życie codzienne w wojsku polskim drugiej połowy XVII wieku, na których temat nie dokonano dotychczas rzetelnego rozpoznania naukowego ${ }^{92}$. Osobną grupę stanowią rozprawy oraz wydawnictwa źródłowe poświęcone problemom zaangażowania wojskowych w życie parlamentarne (np. akta sejmikowe).

\section{BIBLIOGRAFIA}

Biłous N., Testamenty wojskowych polegtych $i$ zmartych na Wołyniu w XVII w., „Kwartalnik Historii Kultury Materialnej” 2016, t. 64, s. 211-224.

Bobiatyński K., Armia jako oręż hetmanów w polityce wewnętrznej w Wielkim Księstwie Litewskim w II połowie XVII wieku (lata 1654-1682) - wybrane zagadnienia, „Studia Historyczno-Wojskowe" 2009, t. III, s. 151-162.

Bobiatyński K., Michał Kazimierz Pac, wojewoda wileński, hetman wielki litewski. Dziatalność polityczno-wojskowa, Warszawa 2008.

Bobiatyński K., W drodze pod Chocim. Litewskie przygotowania do wojny przeciw Turkom w 1673 r. [w:] Studia z dziejów Wielkiego Księstwa Litewskiego (XVI-XVIII wieku), red. S. Górzyński, M. Nagielski, Warszawa 2014, s. 27-47.

Bobiatyński K., Wojsko i polityka - kilka uwag o udziale armii litewskiej w kampaniach przeciw Turkom i Tatarom w latach 70. XVII wieku [w:] Rzeczpospolita państwem wielu narodowości i wyznań, red. T. Ciesielski, A. Filipczak-Kocur, Warszawa-Opole 2008, s. 503-511.

Bobiatyński K., Nagielski M., Testamenty Michała Kazimierza Paca i Aleksandra Hilarego Potubińskiego w przededniu kampanii na Ukrainie przeciwko Turkom i Tatarom w 1675 roku, „Materiały do Historii Wojskowości” 2006, nr 3, cz. 1, s. 125-155.

Chow aniec C., Wyprawa Sobieskiego do Mołdawii w 1686 roku, Oświęcim 2015.

92 Ostatnio ukazała się praca Tadeusza Srogosza, Życie codzienne żolnierzy armii koronnej i litewskiej w XVII wieku, Oświęcim 2018. 
Dybaś B., Fortece Rzeczypospolitej. Studium z dziejów budowy fortyfikacji statych w państwie polsko-litewskim w XVII wieku, Toruń 1998.

Gliwa A., Ostatni napad tatarski na ziemię przemyska z 1699 r., „Studia Historyczne” 2000, R. XLIII, s. 569-591.

Głubisz B., Jazda kozacka w armii koronnej 1549-1696, Poznań 2016.

Górski T., Jan III Sobieski jako wódz, „Teki Gdańskie” 2008-2009, t. 10-11, s. 85-122.

Hetmani zaporoscy w stużbie króla i Rzeczypospolitej, red. P. Kroll, M. Nagielski, M. Wagner, Zabrze 2010.

Hortus bellicus. Studia z dziejów wojskowości nowożytnej. Prace ofiarowane profesorowi Mirosławowi Nagielskiemu, red. K. Bobiatyński [et al.], Biblioteka Epoki Nowożytnej, t. 5, Warszawa 2017.

Hubka M., Jazda polska doby Wazów. Organizacja, uzbrojenie, taktyka, Piotrków Trybunalski 2007.

Hundert Z., Aleksander Polanowski - porucznik husarski i pułkownik Jego Królewskiej Miłości, „Studia z Dziejów Wojskowości” 2013, t. 2, s. 41-70.

Hundert Z., Choragiew husarska Jana Sobieskiego w latach 1673-1676 [w:] Spes in virtute, salus in victoria. Materiały z „IX Ogólnopolskiej Konferencji Studentów Historyków Wojskowości”, Lublin 8-10 grudnia 2011, red. J. Gładysz, D. Lipska, A. Gładysz, Lublin-Zabrze 2013, s. 115-136.

Hundert Z., Choragiew jazdy hospodara multańskiego (wołoskiego) Konstantego Şerbana $w$ wojsku koronnym w latach 1673-1676, „Studia Orientale” 2012, nr 1, s. 191-210.

Hundert Z., Garnizon wojskowy Kamieńca Podolskiego w latach 1667-1672 - zarys problematyki, „Saeculum Christianum” 2014, t. 21, s. 141-153.

Hundert Z., Husaria koronna w wojnie polsko-tureckiej 1672-1676, Oświęcim 2012.

Hundert Z., Husaria pod Chocimiem w 1673 roku [w:] Człowiek i wojna. Z dziejów wojskowości polskiej i powszechnej, red. A. Niewiński, Homo Militans, t. 1, Oświęcim 2013, s. 79-90.

Hundert Z., Jak Mikołaj Skrzetuski zostat rotmistrzem pancernym, czyli kilka uwag o ostatnich latach stużby wojskowej pierwowzoru bohatera ,Trylogii” [w:] Studia nad staropolska sztuka wojenna, t. III, red. Z. Hundert, K. Żojdź, J.J. Sowa, Oświęcim 2014, s. $133-141$.

Hundert Z., Kilka uwag na temat choragwi petyhorskich $w$ wojskach Rzeczypospolitej w latach 1673-1683 [w:] W pancerzu przez wieki. Z dziejów wojskowości polskiej i powszech$n e j$, red. M. Baranowski, A. Gładysz, A. Niewiński, Oświęcim 2014, s. 136-149.

Hundert Z., Komput wojska koronnego na potrzeby podziatu hiberny w 1686 roku [w:] Studia nad staropolska sztuka wojenna, t. V, red. Z. Hundert, K. Żojdź, J.J. Sowa, Oświęcim 2017, s. 314-321.

Hundert Z., Między buława a tronem. Wojsko koronne $w$ walce stronnictwa malkontentów z ugrupowaniem dworskim w latach 1669-1673, Oświęcim 2014.

Hundert Z., Organizacja husarii koronnej na kampanię wiedeńska 1683 roku [w:] „,W hetmańskim trudzie”. Księga pamiątkowa ku czci Jana Wimmera, red. Z. Hundert, M. Wagner, Oświęcim 2017, s. 166-196.

Hundert Z., Powiatowe choragwie kozackie (pancerne) województw poznańskiego i kaliskiego w latach 1671-1673 [w:] Do szarży marsz, marsz... Studia z dziejów kawalerii, red. A. Smoliński, t. 6, Toruń 2015, s. 63-106.

Hundert Z., Projekt organizacji i finansowania ,, Wojska JKM i Rzptej Zaporoskiego” z 1683 roku, „Saeculum Christianum” 2016, t. 23, s. 315-322. 
Hundert Z., Sity ordynacji zamojskiej w latach 1674-1676- przyczynek do badań nad funkcjonowaniem wojsk ordynacji rodowych $w$ XVII wieku [w:] Studia nad staropolska sztuka wojenna, t. IV, red. Z. Hundert, K. Żoj d́, J.J. Sow a, Oświęcim 2015, s. 198-208.

Hundert Z., Szlachta ziemi liwskiej wobec wojska koronnego w latach 1667-1673 w świetle akt sejmikowych, „Studia Mazowieckie” 2017, t. 12 (26), nr 2, s. 13-31.

Hundert Z., Władysław Wilczkowski, porucznik husarski i pułkownik królewski [w:] $\mathrm{Na}$ z góry upatrzonych pozycjach, red. B. Międzybrodzki [et al.], Warszawa-Zabrze 2011, s. $165-173$.

Hundert Z., Wojska zaciagnięte przez samorzą lokalny ziemi warszawskiej w latach 1671 1673, „Almanach Warszawy” 2015, t. 9, s. 71-106.

Hundert Z., Wojsko koronne a elekcja 1674 roku [w:] Wokót wolnych elekcji w państwie polsko-litewskim XVI-XVIII wieku. O znaczeniu idei wyboru-między prawami a obowiązkami, red. M. Markiewicz, D. Rolnik, F. Wolański, Katowice 2016, s. 308-332.

Hundert Z., Wojsko koronne wobec elekcji 1669 roku, „Studia z Dziejów Wojskowości” 2014, t. 3, s. 91-114.

Hundert Z., Wykaz koronnych choragwi i regimentów w okresie 1 V 1679-30 IV 1683. Przyczynek do organizacji wojska koronnego $w$ dobie pokoju 1677-1683, „Studia Historyczno-Wojskowe" 2015, t. V, s. 274-287.

Hundert Z., Wykaz repartycji jednostek wojska koronnego, zgodnie z podziałem komisji lwowskiej w 1679 roku, „Przegląd Historyczno-Wojskowy” 2016, R. XVII, s. 17-34.

Hundert Z., Związi szlachty województwa mazowieckiego z wojskiem w dobie panowania Jana III Sobieskiego - wybrane przykłady [w:] Społeczeństwo polskie i wojsko. Studia i materiaty, [red. K. Maksymiuk, D. Wereda, A. Zawadzki], Siedlce 2016, s. 83-98.

Hundert Z., Sowa J.J., Od towarzysza jazdy do wojewody podolskiego. Przebieg stużby wojskowej Nikodema Żaboklickiego w latach 1656-1706, „Res Historica” 2016, nr 42, 2016, s. 127-181.

Jarzmo Ligi Świętej? Jan III Sobieski i Rzeczpospolita w latach 1684-1696, red. D. Milewski, Warszawa 2017.

Klint P., Testamenty żolnierzy z Wielkopolski i ziemi halickiej z XVII w., „Kwartalnik Historii Kultury Materialnej" 2016, t. 64, s. 197-210.

Kosowski M., Choragwie wołoskie w wojsku koronnym w II pot. XVII wieku, Wojownicy, t. 3, Zabrze 2009.

Król Jan III Sobieski i Rzeczpospolita w latach 1674-1683, red. D. Milewski, Warszawa 2016.

Kupisz D., Wojska powiatowe samorządów Małopolski i Rusi Czerwonej w latach 1572 1717, Lublin 2008.

Majewski A.A., Aleksander Hilary Polubiński (1626-1679), marszałek wielki litewski. Działalność polityczno-wojskowa, Prace Instytutu Historycznego Uniwersytetu Warszawskiego, Warszawa 2017.

Majewski W., Najazd Tatarów w lutym 1695 r., „Studia i Materiały do Historii Wojskowości" 1963, t. IX, s. 125-178.

Markiewicz A., Testament rotmistrza Marcina Ubysza z Mogielnicy z 1690 roku, „,Rocznik Przemyski” 2012, t. 48, s. 21-32.

Markowicz M., Daleko od Wiednia - działania militarne na podolsko-mołdawskim teatrze wojennym na przełomie 1683 i 1684 r., „Studia Historyczno-Wojskowe” 2015, t. VI, s. 91-108. 
Maroń J., Kilka uwag o niefortunnej kampanii 1687 r. [w:] Ślask, Polska, Niemcy, [red. K. Matwijowski, W. Wrzesiński], Acta Universitatis Wratislaviensis. Historia, nr 74, Wrocław 1990, s. 97-104.

Marszałek i hetman koronny Jan Sobieski, red. D. Milewski, Warszawa 2014.

Nagielski M., Hodów 1694-2014. Ostatnie zwycięstwo husarii w wielkim stylu, „Kwartalnik Bellona" 2015, nr 1, s. 229-233.

Nagielski M., Komputy wojska koronnego z 1689 roku jako źródło do składu, struktury i organizacji armii koronnej $w$ dobie panowania Jana III Sobieskiego [w:] Sic erat in votis. Studia i szkice ofiarowane Profesorowi Zbigniewowi Anusikowi w sześćdziesiata rocznice urodzin. Rzeczpospolita w czasach nowożytnych, red. M. Karkocha, P. Robak, Łódź 2017, s. 242-253.

Nagielski M., Listy komendantów Biatej Cerkwi Ottona Ernesta i Krzysztofa Rappe z lat 1681-1682, „Studia Historyczno-Wojskowe” 2006, t. I, s. 255-267.

Nagielski M., Listy z teatru działań przeciwko Turkom i Tatarom do Jana III Sobieskiego z Archiwum Historycznego Białorusi w Mińsku [w:] Państwo, demokracja, chtopi. Studia z historii spoleczno-politycznej Polski (XVII-XX w.). Tom studiów dedykowany profesorowi Romualdowi Wacławowi Turkowskiemu z okazji 65-lecia urodzin i 40-lecia pracy dydaktyczno-naukowej, red. S.J. Pastuszka, J. Sztejnbis-Zdyb, Warszawa 2016, s. 507-521.

Nagielski M., Marcin Kazimierz Kątski generat artylerii koronnej w stużbie króla i Rzeczypospolitej (1656-1710), „Studia Artyleryjskie” 2012, t. 4, s. 133-174.

Nagielski M., Organizacja rajtarii i arkabuzerii koronnej w XVII wieku [w:] Organizacja armii w nowożytnej Europie. Struktura - urzędy - prawo - finanse, red. K. Łopatecki, Zabrze 2011, s. 197-216.

Nagielski M., Bobiatyński K., Jan III Sobieski i Karol Lotaryński w kampanii wiedeńskiej 1683 roku, „De Re Militari” 2015, t. I, s. 76-87.

Poczet hetmanów Rzeczypospolitej. Hetmani koronni, red. M. Nagielski, wyd. 2 popr. i uzup., Warszawa 2005.

Poczet hetmanów Rzeczypospolitej. Hetmani litewscy, red. M. Nagielski, wyd. 2 popr. i uzup., Warszawa 2006.

Rachuba A., Siły zbrojne Wielkiego Księstwa Litewskiego w XVII wieku, „Przegląd Wschodni" 1994, t. III, s. 379-410.

Radziwiłlowie w stużbie Marsa, red. M. Nagielski, K. Żojdź, Warszawa 2017.

Salamon P., Marcin Kazimierz Kątski 1635-1710. Zarys biograficzny, Kraków 2013.

Sawicki M., Artyleria i cekhauz smoleński w 1654 roku [w:] Organizacja armii w nowozytnej Europie. Struktura - urzędy - prawo - finanse, red. K. Łopatecki, Zabrze 2011, s. 313-322.

Sawicki M., Artyleria i cekhauz twierdzy Lachowicze w 1658 roku [w:] Людзі і уллада Навагрудчыны: гісторыя уззаемадзеяння (да 500-годдзя надання Навагрудку прывілея на магдэбургскае права), уклад. А.А. Скеп'ян, В.В. Даніловіч, А.Б. Доўнар, рэд. А.А. Каваленя [et al.], Мінск 2013, s. 191-201.

Sawicki M., Artyleria litewska w latach osiemdziesiatych XVII wieku. Organizacja i finansowanie [w:] Artyleria polska. Historia - teraźniejszość - przyszłość (myśl wojskowa, szkolnictwo artyleryjskie, technika i uzbrojenie). Materiaty pokonferencyjne, III konferencja naukowa, Toruń 11 maja 2009 r. Sympozjum naukowe, Toruń 4 grudnia 2009 r., kom. red. M. Giętkowski, J. Ślipiec, Toruń 2009, s. 161-174.

Sawicki M., Choragwie sapieżyńskie $w$ drugiej połowie XVII wieku w świetle ksiag litewskich komisji skarbowo-wojskowych [w:] Вялікае Княства Літоўскае: палітыка, 
эканоміка, культура: зборнік навуковых артыкулай: у дзвюх частках, Ч. 1, уклад. А.А. Скеп’ян, рэд. У.Р. Гусакоў [et al.], Мінск 2017, s. 409-418.

Sawicki M., Twierdza radziwillowska $w$ Birżach $w$ XVII wieku. Artyleria i cekhauz [w:] W'́ród dymu i ognia. Studia z dziejów artylerii, t. 2, red. A. Smoliński, Toruń 2016, s. $13-35$.

Sikora R., Fenomen husarii, Warszawa 2013.

Sikora R., Husaria pod Wiedniem 1683, Warszawa 2012.

Smolarek P., Kampania mołdawska Jana III roku 1691, do druku przygotowali Z. Hundert, M. Wagner, Oświęcim 2015.

Sowa J.J., Jednostki komputowe Adama Mikołaja Sieniawskiego do 1702 r., cz. 1: Udziat $w$ działaniach wojennych do 1696 roku [w:] Studia nad staropolska sztuka wojenna, t. IV, red. Z. Hundert, K. Żojdź, J.J. Sowa, Oświęcim 2015, s. 209-221.

Sow a J.J., Jednostki komputowe Adama Mikołaja Sieniawskiego do 1702 r., cz. 2 [w:] Studia nad staropolska sztuka wojenna, t. V, red. Z. Hundert, K. Żojdź, J.J. Sowa, Oświęcim 2017, s. 247-264.

Sow a J.J., Ludzie niezwalczeni. Rejestry choragwi jazdy autoramentu narodowego w Okopach Świętej Trójcy 1693-1695 [w:] Studia nad staropolska sztuka wojenna, t. II, red. Z. Hundert, Oświęcim 2013, s. 259-299.

Sow a J.J., ,, $W$ czym veritur powaga moja hetmańska...”. Organizacja i procedura sadu hetmańskiego w Koronie w latach 1683-1699, „Czasopismo Prawno-Historyczne” 2013, t. 65 , z. 1, s. 203-228.

Społeczeństwo a wojsko, [red. I.M. Dacka-Górzyńska, A. Karpiński, M. Nagielski], Społeczeństwo Staropolskie. Seria Nowa, t. IV, Warszawa 2015.

Srogosz T., Życie codzienne żotnierzy armii koronnej i litewskiej w XVII wieku, Oświęcim 2018.

Szlezynger P.S., Inwentarze cekhauzów i armaty zamkowej w XVII i XVIII wieku w magnackich fortecach $w$ Wiśniczu, Połonnem, Dubnem i Żótkwi, „Studia i Materiały do Historii Wojskowości” 2003, t. XL, s. 283-330.

Traktaty karłowickie z 1699 roku i ich nastęstwa, red. I. Czamańska, W. Szulc, Poznań 2003.

Wagner M., Baltazar Wilga Godzimirski - ostatni komisarz kozacki Rzeczypospolitej (1692 1699), „Zeszyty Naukowe Uniwersytetu Jagiellońskiego. Prace Historyczne” 2016, nr 2 (143): Ukraina, Ruś w epoce nowożytnej. Instytucje i elity, red. J. Stolicki, W. Michałowski, s. 327-334.

Wagner M., Formacje dragońskie armii koronnej w czasach Jana III Sobieskiego. Lata 1667-1696 [w:] Do szarży marsz, marsz... Studia z dziejów kawalerii, red. A. Smoliński, t. 5, Toruń 2014, s. 105-146.

Wagner M., Frejkompania dragońska artylerii koronnej w końcu XVII wieku. Z dziejów modernizacji wojska polskiego $w$ dobie Jana III Sobieskiego [w:] Modernizacja życia społeczno-gospodarczego i politycznego na ziemiach polskich, red. J. Cabaj, K. Maksymiuk, D. Wereda, Siedlce 2017, s. 23-34.

Wagner M., „Inna wojna Sobieskiego”. Polskie formacje nieregularne i ochotnicze w wojnie polsko-tureckiej (1672-1676) [w:] Studia z dziejów Wielkiego Księstwa Litewskiego (XVI-XVIII wieku), red. S. Górzyński, M. Nagielski, Warszawa 2014, s. 435-446.

Wagner M., Jan Fryderyk von der Groeben (1645-1712) - generat wojska polskiego i dyplomata Jana III Sobieskiego [w:] Bezpieczeństwo - edukacja - wychowanie. Księga jubileuszowa dedykowana Profesorowi Jerzemu Kunikowskiemu, t. 1, red. T. Zacharuk, M. Minkina, B. Czeluścińska, Siedlce 2015, s. 355-360. 
Wagner M., Jerzy Wołodyjowski (około 1620-1672) rotmistrz piechoty i stolnik przemyski [w:] ,,W hetmańskim trudzie”. Księga pamiątkowa ku czci Jana Wimmera, red. Z. Hundert, M. Wagner, Oświęcim 2017, s. 152-165.

Wagner M., Kampania mołdawska 1690 roku [w:] Na wojnie i w szlacheckim dworku. Studia i materiały, [red. K. Maksymiuk, D. Wereda, R. Roguski], Siedlce 2016.

Wagner M., Kampania żwaniecka 1684 roku, Warszawa 2013.

Wagner M., Kawaleria koronna w dobie panowania Jana III Sobieskiego. Lata 1683-1696 [w:] Do szarży marsz, marsz ... Studia z dziejów kawalerii, red. A. Smolińs ki, t. 3, Toruń 2012, s. 67-112.

Wagner M., Korpus oficerski wojska polskiego w drugiej połowie XVII wieku, Oświęcim 2015.

Wagner M., Perspektywy edycji nowożytnych źródet historyczno-wojskowych z XVII-XVIII wieku [w:] Edytorstwo źródet - ograniczenia i perspektywy, red. A. Perłakowski, Kraków 2015, s. 69-90.

Wagner M., Słownik biograficzny oficerów polskich drugiej połowy XVII wieku, t. I-III, Oświęcim 2013, 2014, 2018.

Wagner M., ,Sprawy kozackie” w rachunkach hetmana wielkiego Stanisława Jabłonowskiego w latach 1685-1689 [w:] Wczesnonowożytny człowiek. Przestrzeń - władza-prawo w XVI-XVIII wieku, red. W. Michałowski, J. Stolicki, Patrimonium, t. 1, KijówKraków 2015, s. 328-338.

Wagner M., ,, Sprawy mołdawskie” w rachunkach hetmana wielkiego koronnego Stanistawa Jabłonowskiego w latach 1685-1689 [w:] Ze wspólnej przeszłości. Studia z dziejów stosunków polsko-rumuńskich, red. A. Smoliński, Toruń 2017, s. 11-23.

Wagner M., Stanisław Jabłonowski (1634-1702). Polityk i dowódca, t. I-II, Siedlce 1997. Wagner M., Wojna polsko-turecka w latach 1672-1676, t. I-II, Zabrze 2009.

Wagner M., Wydatki wojskowe hetmana wielkiego koronnego Stanisława Jabłonowskiego w latach 1685-1689 [w:] Pecunia nervus belli. Z dziejów dyplomacji i stosunków międzynarodowych $w X V-X V I I I$ wieku, red. M. Markiewicz, R. Skowron, F. Wolański, Prace Naukowe Uniwersytetu Śląskiego w Katowicach, nr 3448, Katowice 2016, s. 226-238.

Wagner M., Zapomniany Hektor. Generat Jan Michat Żebrowski (około 1630-1676) [w:] Kadry decyduja o wszystkim. Studia z zakresu biografistyki wojskowej, red. J. Jędry siak [et al.], Wrocławskie Studia z Historii Wojskowości, t. 4, Wrocław 2015, s. 219-236.

Wagner M., Źródła do dziejów wojny polsko-tureckiej w latach 1683-1699, Oświęcim 2016.

Wasilewski W., Wyprawa bukowińska Stanisława Jabłonowskiego w 1685 roku, Warszawa 2002.

Wierzbicki L.A., Pospolite ruszenie w Polsce w drugiej połowie XVII wieku. Ostatnie wyprawy z lat 1670-1672, Lublin 2011.

Wimmer J., Historia piechoty polskiej do roku 1864, Warszawa 1978.

Wimmer J., Wiedeń 1683. Dzieje kampanii i bitwy, Warszawa 1983.

Wimmer J., Wojsko polskie w drugiej połowie XVII wieku, Warszawa 1965.

Wimmer J., Wojsko polskie w drugiej połowie XVII wieku, wyd. 2 poszerz., Oświęcim 2013.

Witkowicz A., Czerwone sztandary Osmanów. Wojna roku 1683 opisana na nowo, Warszawa 2016.

Wojtasik J., Ostatnia rozprawa zbrojna z Turkami i Tatarami w 1698 roku, „Studia i Materiały do Historii Wojskowości” 1967, t. XIII, cz. 1, s. 63-127, cz. 2, s. 111-183.

Wojtasik J., Podhajce 1698, Warszawa 1990. 
Woliński J., Wojskowość polska w dobie Jana III Sobieskiego (stan i problemy badań) [w:] idem, $Z$ dziejów wojny i polityki w dobie Jana Sobieskiego, red. M. Anusiewicz, Warszawa 1960, s. 186-192.

Wójcik Z., Jan Sobieski 1629-1696, Warszawa 1983.

Zamki, twierdze i garnizony Opola, Ślaska i dawnej Rzeczypospolitej, red. T. Ciesielski, Zabrze 2010.

Życiński S., Inwentarz pozostałości po Jerzym Wołhodyiowskim pułkowniku choragwi laudańskiej z roku 1672, „Zeszyt Naukowy Muzeum Wojska w Białymstoku” 1988, nr 12, s. 159-161. 